Drawing for young children, by Mr. E. B. Sargant. The author said it was well recognised at the present day that the old plan of beginning to teach drawing by making the children produce a series of straight lines tended to disgust young children with the subject for their whole school life. It was much easier to draw circles than straight lines, as appeared natural if the mechanism of the arm was considered. It was also better to begin with drawing rather than with writing, and to practise from the shoulder at first, then from the elbow, and finally from the wrist and fingers. This plan prevented the straining of the eyes at a time when short sight was likely to be produced very early. There was also a great deal to be said for beginning with the brush and colour rather than with the pencil or chalk. Mr. Sargant then proceeded to consider in detail the code of the Orange River Colony, which gave effect in drawing to these principles.

\section{General Business.}

At a council meeting of the association on April 4, Sir Charles Metcalfe, the president, alluded to the visit of the British Association to Johannesburg next year, and said he had been in frequent correspondence with members of the committee which had been appointed in England, including Sir Norman Lockyer and Prof. Dewar. Everything is now settled except the route, the fixing of which it has been considered better to postpone until nearer the date There is also the question as to who should be president for the year, and though this has not been decided yet, there was no doubt there would be a very good president coming out for the meetings. The greatest man of science of the day, Lord Kelvin, who would be eighty-one years of age next year, was resolved to come. With regard to the status of members of the South African Association, they would naturally be entitled to attend all the meetings of the British Association. The proposal was that there should be three days' meetings at Cape Town and three days' meetings at Johannesburg, with shorter sessions at Durban, Kimberley, Bulawayo, and other places visited.

Sir Charles Metcalfe also referred to the arrangements to be made in connection with the visit of the British Association at the annual business meeting of the South African Association. Certain local papers will be read, and these will be chosen by the local committees of the places where meetings are held, so that those who come from distances may have the opportunity of hearing a good paper dealing with the chief object of interest in that particular centre.

\section{THE NEW ZEALAND VEGETABLE CATER PILLAR.}

FEW among the smaller natural productions of New Zealand have attracted more attention than the socalled vegetable caterpillar of New Zealand, of which we have just received a very fine specimen from Messrs. Armbrecht, Nelson and Co., of Duke Street, Grosvenor Square, W. Fungoid parasites are sufficiently common in all parts of the world, but are not generally conspicuous enough to be much noticed by any persons but naturalists. Many of the largest and most remarkable moths of the Australian region belong to the families Cossidæ and Hepialidæ, represented in Europe by our goat moth and swifts, and the caterpillars of several species of these are known to be infested by various parasitic fungi belonging to the genus Cordyceps, Fries, which convert the whole substance of the caterpillar into a woody substance, and then sprout from it to a length of several inches.

As in the case of larvæ attacked by insect parasites, these (which are usually about four inches long when full grown) live until they are ready to assume the pupa state, when they bury themselves in the ground, die, and the fungus sprouts upwards, generally from the neck of the caterpillar, sometimes acquiring the length of nearly a foot, and sprouting up from the ground above the caterpillar. Very rarely two, or even three, of these filaments may sprout from a single caterpillar. The best known species is Cordyceps Hugelii, Corda (Sphaeria Robertsii, Hooker), which is extremely abundant in New Zealand.

"The New Zealander's name for this plant-caterpillar is No. 1802 , VOL. 70]
Hotete, Aweto, Weri, and Anuhe. The natives eat the plants, which when fresh have the flavour of a nut, and also use them, when burnt, as colouring matter for their tattooing, rubbing the powder into the wounds, in which state it has a strong animal smell" (Gray, "Notices of Insects that are Known to Form the Bases of Fungoid Parasites" (1858), p. 6, note quoting from Taylor). Almost every writer in New Zealand has discussed the vegetable caterpillar in more or less detail, notably Taylor and Hochstetter, in addition to Gray's important paper quoted above. Mr. G. Massee's "Revision of the Genus Cordyceps" (Annals of Botany, vol. ix. pp. I-44, pls. i. and ii., March, I895) may also be consulted.

It is probable that more than one species of New Zealand caterpillar is infested by, perhaps, more than one species of Cordyceps. C. Hugelii (Robertsii) is usually said to be parasitic on the larva of the large green moth Hepialus (GEnetus) virescens, Doubleday, but Mr. G. V. Hudson points out in his "New Zealand Moths and Butterfiles" (p. 132) that this cannot be the case, because the larva of that insect burrows in the wood of trees, and forms its pupa in the galleries, and not in the ground. He suggests that it may infest the larva of Porina Mairi, Buller, a brown moth with black and white spots and markings; but this seems equally improbable, for this is a very rare moth, of which very little seems to be known. More information on these curious parasites and their hosts is very desirable.

W. F. KIRBX.

\section{UNIVERSITY AND EDUCATIONAL INTE LLIGENCE.}

OXFORD.-A meeting of the University Junior Scientific Club was held on May 4. Mr. H. B. Hartley exhibited an unpublished portrait of Sir Richard Owen. Mr. A. S. MacNalty read a paper on William Harvey.

The eleventh Robert Boyle lecture will be delivered on June 3 in Balliol College Hall by Prof. J. J. Thomson, F.R.S. His subject will be "The Structure of the Atom."

The Romanes lecture will be delivered by Sir Courtenay Peregrine Ilbert, K.C.S.I., Balliol College, on Saturday, June 4 , at 3 p.m., in the Sheldonian Theatre. The subject of his discourse will be "Montesquieu."

A meeting was held in the schools on Friday, May 6, to discuss the question of the organisation of post-graduate study. The president of Trinity was in the chair. The meeting was largely attended by those who are interested in the encouragement of research. Prof. Poulton moved a resolution advocating the expediency of "the further utilisation of fellowships for the purposes of research." This was seconded by Profs. Ellis and Gardner, and carried unanimously. Dr. Farnell moved a resolution favouring "the better organisation of the teaching resources of Oxford." He wished to see the boards of faculty take a more active part in organising the teaching resources, which now suffer from considerable dislocation. The boards ought to be able to give the status of protessor to a college tutor, and assign him an income from university funds. The general principle of Dr. Farnell's resolution was carried.

Cambridge.- Sir Michael Foster has been re-appointed a manager of the Balfour (Animal Morphology) Fund.

Applications for leave to occupy the university tables at the Naples and Plymouth Zoological Stations are to be sent to Dr. Harmer, King's College, by May 26.

Mr. Frank G. Smart, M.B., has generously endowed a university studentship for research in botany of the value of rool. a year for two years. The first election will be made in July.

The Board of Agricultural Studies reports the continued progress of the department; which last term had forty students. A number of field experiments have been instituted, and are in progress on the university farm and in the adjoining counties, under the supervision of Prof. Middleton and his staff.

The Drapers' Company has decided to grant ${ }_{15,500 l}$ to the University College of South Wales for the purpose of erecting the structure of the proposed new library, in lieu of ro,oool. conditionally granted in 1895 . 